\title{
EFFECT OF ANTITUBERCULOSIS TREATMENT ON SERUM ZINC LEVEL IN TUBERCULOSIS
}

\author{
Bhandari S. ${ }^{1}$, Neupane Y. ${ }^{2}$, Badade Z.G.. ${ }^{3}$ Potdar P. ${ }^{4}$,
}

\begin{abstract}
INTRODUCTION: Tuberculosis is a major public health problem worldwide. One third population of world is infected with M. tuberculosis. Zinc is micro-mineral essential for human growth, development and immune function. Deficiency of this micronutrient impairs overall immune function and resistance to infection. Present study was conducted to evaluate the level of serum zinc in patients with tuberculosis at various period of treatment.
\end{abstract}

METHODS: Total 92 subjects included were evaluated from OPD, IPD and DOTS centre of MGM group of Hospitals, Navi Mumbai, India. Among them there were 50 patients with Tuberculosis and 42 normal healthy controls. In all the subject estimation of Zinc was carried out. Out of 50 tuberculosis patients, 31 patients were assessed for zinc after two months and six months (i.e. completion) of DOTS therapy. The assessment was done according to the cut off values of serum zinc i.e. 60 $120 \mu \mathrm{gm} / \mathrm{dl}$.

RESULTS: Serum zinc levels were significantly low $(\mathrm{p}<0.001)$ in study group as compared to the healthy control. Serum zinc concentration of the patients increased gradually after anti-tuberculous therapy and reached normal levels after completion of therapy.

CONCLUSION: In the present study serum zinc levels of patients with pulmonary tuberculosis was found low as compared to healthy control subjects. Supplement of zinc during the treatment can be important for the betterment of the treatment of this disease.

\section{KEY WORDS: Tuberculosis, Zinc Therapy}

1. Lecturer, Department of Biochemistry, Gandaki Medical College, Pokhara, Nepal

2. Lecturer, Department of Biochemistry, Universal College of Medical Sciences \& Teaching Hospital, Bhairahawa, Nepal

3. Professor, Department of Biochemistry, MGM Medical College, Kamothe, Navi Mumbai, India

4. Professor, Department of TB and Respiratory Medicine; MGM Medical College, Kamothe, Navi Mumbai, India

\author{
For Correspondence \\ Mr. Suresh Bhandari, \\ Lecturer, \\ Department of Biochemistry, \\ Gandaki Medical College, \\ Pokhara, Nepal \\ Email:princesureesh@hotmail.com
}




\section{INTRODUCTION}

Tuberculosis (TB) is a contagious disease caused by organism Mycobacterium tuberculosis, aerobic non motile bacillus. The tuberculosis bacteria can attack any part of the body, most commonly the lungs. It spreads through air, when infectious people cough, sneeze, talk or spit; they propel TB germs known as bacilli into air. Inhalation of very small numbers of these bacilli will lead to M. tuberculosis infection. ${ }^{1}$ One third population of world is infected with $\mathrm{M}$. tuberculosis. The vast majority of these have latent infections. Annually, more than 8 million people develop tuberculosis (TB), and approximately 1.8 million cases result in death. ${ }^{2}$ although tuberculosis is a curable disease, it continues to be prevalent and causes death. Without aggressive public health measures and continued research, effective treatments or vaccine development, this treatable disease will continue to be rampant. ${ }^{3}$ Zinc is micromineral essential for human growth, development and immune function. Deficiency of this micronutrient impairs overall immune function and resistance to infection. ${ }^{4}$

\section{MATERIAL AND METHODS}

Study was carried out in 92 subjects. There were 42 normal healthy individuals and 50 patients with Tuberculosis. All the subjects were selected from OPD, IPD and DOTS centre of MGM group of Hospitals, Navi Mumbai and estimation of serum zinc was carried out. Out of 50 tuberculosis patients, 31 patients were assessed after two months and six months (i.e. completion) of DOTS therapy. The patients were given the combination of drugs consisting of rifampicin, isoniazid, pyrizinamide and ethambutol as per RNTCP (DOTS) regimen. The control group comprises of healthy subjects of both sexes. Venous Blood samples were obtained from tuberculosis patients (at the time of diagnosis, after two months and on completion of DOTS therapy) and healthy controls. The diagnosis of tuberculosis was based on clinical, radiological, sputum Acid Fast Bacillus (AFB) smear positivity and tuberculin skin test positivity.

Serum Zinc was estimated by Coral Kit method. Zinc in an alkaline medium reacts with Nitro- PAPS to form a purple colored complex. Intensity of the colored complex is directly proportional to the amount of zinc present in the sample.

\section{Zinc + Nitro-PAPS $\stackrel{\text { alkaline medium }}{\longrightarrow}$ purple colored complex}

\section{RESULTS}

Control group: Forty two normal healthy individuals aged between 20 to 60 years of age [ 27 males $(64.28 \%)$ and 15 females $(35.72 \%)$ ] were included as controls. In this group the mean \pm SD of the serum Zinc was found to be $93.30 \pm 10.03$ $\mu \mathrm{gm} / \mathrm{dl}$.
Study group: Fifty newly diagnosed tuberculosis patients were included in the study. Out 50 patients, in 31 patients the serum zinc levels was also estimated during treatment and on completion of therapy. In present study, mean serum zinc levels in newly diagnosed tuberculosis patients was (59.88 \pm $7.82 \mu \mathrm{gm} / \mathrm{dl})$. The mean serum zinc level in control subjects was found to be $(93.30 \pm 10.03 \mu \mathrm{gm} / \mathrm{dl})$. The mean serum zinc level in patients after two months and on completion (six months) of anti tubercular therapy was found to be (74.70 \pm $6.50 \mu \mathrm{gm} / \mathrm{dl})$ and $(99.82 \pm 14.23 \mu \mathrm{gm} / \mathrm{dl})$ respectively. No significant difference was observed in mean serum zinc level in different sex and age groups among these patients.

Table 1: Comparisons of Serum Zinc in Control groups and different study groups.

\begin{tabular}{|c|c|c|c|c|}
\hline \multirow{2}{*}{} & & \multicolumn{3}{|c|}{ Study Groups } \\
\cline { 3 - 5 } Parameter & Control Group & $\begin{array}{c}\text { Newly } \\
\text { Diagnosed TB } \\
\text { Patient } \\
(\text { mean } \pm \mathrm{SD})\end{array}$ & $\begin{array}{c}\text { Patients after two } \\
\text { months of } \\
\text { therapy } \\
\text { (mean } \pm \mathrm{SD})\end{array}$ & $\begin{array}{c}\text { Patients on } \\
\text { completion of } \\
\text { therapy } \\
(\text { mean } \pm \mathrm{SD})\end{array}$ \\
\hline ZINC $(\mu \mathrm{ggm} / \mathrm{dl})$ & $93.30 \pm 10.03$ & $59.88 \pm 7.82 *$ & $74.70 \pm 6.50$ & $99.82 \pm 14.23$ \\
\hline
\end{tabular}

$* \mathrm{p}<0.001$ (statistically highly significant)

Figure 1: Serum Zinc ( $\mu \mathrm{gm} / \mathrm{dl})$

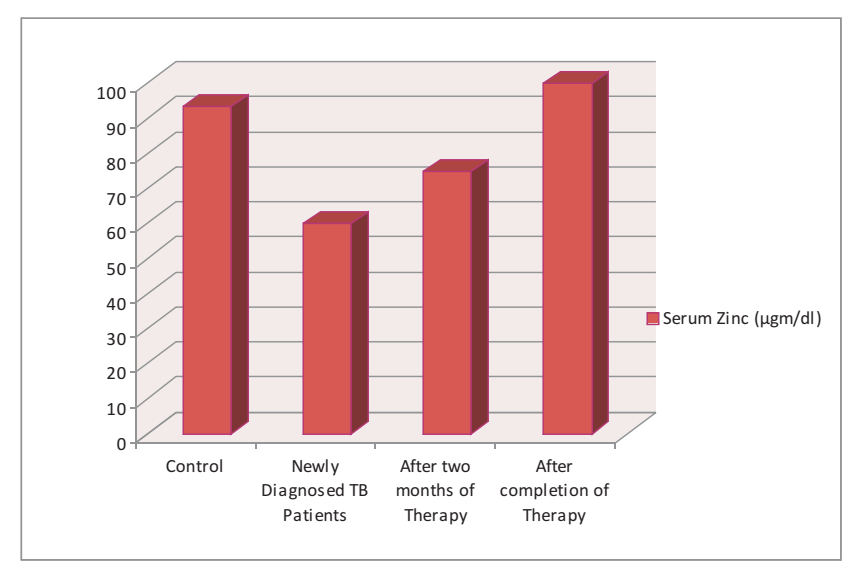

\section{DISCUSSION}

In our study we observed that the mean serum zinc concentration was significantly decreased in tuberculosis patients as compared to the control $(\mathrm{P}<0.001)$. Also we found that the mean serum zinc concentration was significantly increased in the patients after the completion of DOTS therapy $(\mathrm{P}<0.001)$. We found serum zinc concentration of the patients increased gradually after anti-tuberculous therapy and reached normal levels after completion of therapy. 
Similar study was carried out by Hassan Ghulam et al. ${ }^{5}$ and reported that the mean serum zinc concentration in pulmonary tuberculosis group prior to therapy showed a significant fall $(\mathrm{P}<0.05)$ in average serum zinc levels in contrast to the control group. In India, Ray M et al. ${ }^{6}$ studied the plasma zinc status of 50 children with tuberculosis and compared the observations with 10 healthy and 10 malnourished children without tuberculosis at 0,1,2,3 and 6 months of anti-tubercular therapy. The children with tuberculosis had significantly lower plasma zinc levels than those without the disease, irrespective of the nutritional status. Similarly, Karyadi et al. ${ }^{7}$ from Indonesia studied the nutritional status of patients with active pulmonary tuberculosis and compared the values with those of healthy controls and found poor nutritional status and significantly low serum zinc levels in tuberculosis patients compared to control.

Contrary to previous studies and the present one, Ciftci et al. ${ }^{8}$ from Turkey studied 22 pulmonary TB patients and 18 healthy subjects and found an increase in the levels of zinc; however the mechanism of this increase was not explained. Similar study from Japan reported higher mean serum zinc level $(12.39 \pm 2.17 \mathrm{mmol} / \mathrm{L})$ in patients with pulmonary TB. ${ }^{9}$

The reason for the low serum zinc levels in TB could be multifactorial. Firstly, a change in distribution of zinc in the body tissues is known to occur in chronic infections, with a net flow of zinc to the liver for the synthesis of acute phase reactants including metalloenzymes. Secondly, zinc may be utilized by tuberculosis for growth and multiplication. ${ }^{10}$

\section{CONCLUSION}

In the present study serum zinc levels of patients with pulmonary tuberculosis was evaluated and it was found that these patients had low serum concentration of zinc as compared to control subjects. This was likely due to the redistribution of zinc from plasma to other tissues, reduction of hepatic production of zinc-carrier protein $\alpha_{2}$-macroglobulin and a rise in the production of metallothionin, a protein that transports zinc to the liver. The concentration of serum zinc was found to be increased after the anti tuberculosis therapy. Zinc supplementation can be suggested as a treatment protocol for the betterment of treatment.

\section{REFERENCES}

1. http://www.who.int/mediacentre/factsheets/fs104/en

2. The Global Tuberculosis Control 2011.2011 Geneva: World Health Organization.

3. Perlin D, Cohen A, Perlin DS. The Complete Idiot's Guide to Dangerous Diseases \& Epidemics 2002.

4. Walker CF, Black RE. Zinc and the risk for infectious disease, Annu Rev Nutr. 2004, 24: 255-275.

5. Ghulam H, Kadri SM, Manzoor A, Waseem Q, Aatif MS, Khan $G Q$, Manish K. Status of Zinc in pulmonary tuberculosis. $J$ Infect Dev Ctries 2009; 3(5): 365-368.

6. Ray M, Kumar L, Prasad R. Plasma zinc status in Indian Childhood tuberculosis: impact on antituberculosis therapy. Int. J. Tuberc Ling Dis. 2: 719-25

7. Karyadi E, Schultink W, Ronald HH et al. Poor Micronutrient Status of Active Pulmonary Tuberculosis Patients in Indonesia. American Scoiety for Nutritional Sciences, 2000; 2953-8.

8. Ciftci TU, Cifti B, Yis O, Guney Y, Bilgihan A, Ogretensoy M. Changes on serum selenium, copper, zinc levels and cu/zn ratio in patients with pulmonary tuberculosis during therapy. Biol. Trace Elen Res. 2003; 95:65-71.

9. Kassu A, Yabutani T, Mahmud ZH, Mohammad A, Nguyen N, Huong BT, Hailemariam G, Diro E, Ayele B and Wondmikun Y. Alterations in serum levels of trace elements iin tuberculosis and HIV infections. Eur. J. Clin. Nutr., 2006; 60(5): 580-6.

10. Liu $X$ et al. [Determination of trace elements in serum of tuberculosis patients]. Jiu WSY, 2000; 29(6): 395-6 [in Chinese]

\section{UCMS College of Dental Surgery}

\section{is having following post graduation (MDS) programmes:-}

1. Oral \& Maxillofacial Surgery.

2. Periodontology \& Implantology.

3. Conservative \& Endodontics.
4. Orthodontics \& Dentofacial Orthopaedics.

5. Prosthodontics \& Maxillofacial Prosthesis 